Journal of Agriculture and Food Sciences

Volume 19 Number 1, April 2021 pp 63-77
Ariyo, O., Balogun, B., and Solademi E. A.

\title{
EFFECT OF ACCELERATED RIPENING AGENT ON NUTRIENT AND ANTINUTRIENT COMPOSITION OF BANANA
}

\author{
Ariyo, O. ${ }^{* 1}$, Balogun, B. ${ }^{2}$, and Solademi E. A. ${ }^{1}$ \\ ${ }^{1}$ Department of Human Nutrition and Dietetics, University of Ibadan, Nigeria \\ ${ }^{2}$ Chemistry/Biochemistry Unit, Nigerian Stored Products Research Institute, Ibadan, Nigeria \\ *Corresponding email address: ariyoseun@gmail.com
}

\begin{abstract}
Food safety especially of fruits is important for a healthy and sustainable food system. Though accelerated ripening of fruits is common in Nigeria, its effect on nutritional quality of fruits remains underexplored. This study was conducted to investigate the changes in the nutrient and antinutrient composition of banana ripened with Calcium carbide $\left(\mathrm{CaC}_{2}\right)$. In this study, mature bunches of freshly harvested green bananas were grouped separately and allowed to ripen naturally and artificially (with $\mathrm{CaC}_{2}$ ). At the end of the ripening stage, the nutritional parameters (proximate, minerals, vitamins) and antinutritional parameters were determined using relevant analytical methods, and the results obtained were compared across groups. The results showed that the proximate composition of the artificially ripened samples increase in ash (1.49), fat (0.76), and moisture (69.86) while carbohydrate (23.92) and protein (1.88) contents declined. Similarly, $\mathrm{Na}, \mathrm{K}, \mathrm{Ca}, \mathrm{Mg}, \mathrm{P}, \mathrm{Fe}$ and $\mathrm{Zn}(\mathrm{mg} / \mathrm{lOO} \mathrm{g})$ contents were higher in calcium carbide ripened than naturally ripened sample. Naturally ripened samples contained the higher amount of Vitamins $C(28.87 \mathrm{mg} / 100 \mathrm{~g})$, niacin $(0.89 \mathrm{mg} / 100 \mathrm{~g})$, pantothenic acid $(0.27 \mathrm{mg} / 100$ $\mathrm{g})$ and pyridoxine $(0.29 \mathrm{mg} / 100 \mathrm{~g})$. The $\beta$-carotene $(127 \mathrm{mcg} / 100 \mathrm{~g})$, Vitamin $E(2.9 \mathrm{mg} / 100 \mathrm{~g})$ and Vitamin $K(0.31 \mathrm{mg} / 100 \mathrm{~g})$ increased significantly in the artificially ripened samples, when compared to the naturally ripened samples. The use of calcium carbide as a ripening agent increases moisture and phlobatannin content, and loss in protein, carbohydrate, fibre, niacin, pantothenic acid, and pyridoxine composition of Cavendish banana.
\end{abstract}

Keywords: Cavendish, calcium carbide, nutritional quality, anti-nutrient

https://dx.doi.org/10.4314/jafs.v19i1.5

\section{INTRODUCTION}

Banana (Musa spp., Family Musaceae) is one of the most traded tropical fruits worldwide, recorded as the fourth largest food crop. In Africa, it is a very common and popular economic crop, which serves as a major source of income for more than 70 million people around the continent (FAO 2019). Akinyemi et al. (2017) reported that in South-western Nigeria, the cultivation of Cavendish banana is practiced to a large extent and as a result, the fruits are extremely affordable and readily available all year round compared to other fruits. 
Journal of Agriculture and Food Sciences

Volume 19 Number 1, April 2021 pp 63-77

Ariyo, O., Balogun, B., and Solademi E. A.

Bananas are grown majorly for their nutritious and delicious ripe fruits, and its consumption cuts across many segments of the society, including all age groups due to the fact that it is highly digestible and it supplies the necessary calories and essential micronutrients required (Mesquita et al., 2016; Tejas et al., 2019). According to Oyeyinka and Afolayan (2020), bananas are known to offer numerous health benefits as its edible portion contains carbohydrates and fibre that act as long-lasting form of fuel and helps to stabilize blood sugar levels. Also, it contains vitamins $\mathrm{C}, \mathrm{A}$ and B complexes, among other nutrients and it is a good source of potassium and magnesium; relevant to maintain nerve and muscle function, in addition to maintaining $\mathrm{pH}$ and fluid balance (Rahman et al., 2019; Oyeyinka and Afolayan, 2020).

According to Perotti et al. (2014) and Maduwanthi and Marapana (2019), the ripening process introduces numerous qualities and nutritional characteristics to fruits. The process of fruit ripening is the final stage of fruit development, which is a combination of a series of physiological and biochemical events leading to changes in pigments, sugar content, acid content, flavour, texture and aroma that makes the fruit attractive and tasty (Perotti et al., 2014). Fruits can be classified as climacteric and non-climacteric, depending on the ripening pattern. The climacteric stage of fruit ripening is associated with increased production and release of ethylene and an up-regulated cellular respiration. Since banana is a climacteric fruit, it is typically harvested at the preclimacteric stage (mature but unripe condition) and allowed to ripen (Maduwanthi \& Marapana, 2019). Though this practice reduces post-harvest losses of banana especially during transportation; it is often accompanied with induced ripening with artificial agents (ethylene glycol, kerosene, ether, calcium carbide etc.) to meet consumers' demands and other economic factors (Abhishek et al., 2016). These artificial ripening agents if used inappropriately are toxic and their consumption may cause health problems; such as skin disease, cancers, neurological disorders and organ failure (Krishna et al., 2017).

Calcium carbide $\left(\mathrm{CaC}_{2}\right)$ is a chemical compound, considered hazardous due to several reasons, but it is widely used for artificial ripening of bananas regardless of the policies surrounding its use in many developing countries (Islam et al., 2018; Nuhu et al., 2020). Research has shown that the chemical causes a variety of side effects on human health, ranging from irritation of skin, eyes, chest and abdomen, vomiting, to burning sensations, seizures and coma even at low concentrations (Nura et al., 2018). 
Journal of Agriculture and Food Sciences

Volume 19 Number 1, April 2021 pp 63-77

Ariyo, O. , Balogun, B., and Solademi E. A.

Following the increased national and global drives for healthy and sustainable food system, ensuring food safety along the fruits value chain is important to optimize nutritional composition. Hence, this study was conducted owing to the scarcity of scientific information on the effect of accelerated ripening agent on nutrient and anti-nutrient composition of banana cultivated in the South-western region of Nigeria.

\section{MATERIALS AND METHODS}

\section{Sample procurement}

Freshly harvested bunches of mature green banana samples used in this study were obtained from International Institute of Tropical Agriculture, Ibadan. All reagents used were of analytical grade.

\section{Sample treatment}

The collected bunches of mature green banana samples were cleaned and taken into the laboratory for further treatment. The samples were separated into two treatment groups of approximately the same weight and each group was placed under the same atmospheric condition.

Naturally ripened group (NR): The untreated group in which samples were allowed to ripen naturally over a period of 96 hours, without any ripening agent.

Artificially ripened group (AR): The group in which samples were treated with calcium carbide $\left(\mathrm{CaC}_{2}\right)$. The wholesome samples were placed in a container and then, $10 \mathrm{~g}$ of calcium carbide powder carefully wrapped in polythene bag was placed at the middle of the container. The samples were checked at intervals and the ripeness was determined by change in skin colour (green to yellow), and texture. After 72 hours it was discovered that the banana in the container with Calcium carbide was fully ripened.

\section{Laboratory analysis}

\section{Determination of proximate composition}

The proximate composition (moisture, crude protein, crude fat, ash, crude fibre, carbohydrate contents and energy value) of the samples was determined using the standard methods of the 
Journal of Agriculture and Food Sciences

Volume 19 Number 1, April 2021 pp 63-77

Ariyo, O., Balogun, B., and Solademi E. A.

Association of Official Analytical Chemists (2005). The moisture content was determined using air oven at $105{ }^{0} \mathrm{C}$ to a constant weight according to Method No 967.08 (Plus 11 Sanyo Gallenkamp UK), crude protein was determined using mico-Kjeldahl method (Method No 978.04), and crude fat was determined by the Soxhlet extraction method (Method No 2003.06). The ash content was determined by ashing the sample in a muffle furnace (Gallenkamp 3) at 550 ${ }^{0} \mathrm{C}$ for 4 hours (Method No 942.05), while crude fibre was determined by Method No. 958.06. The total carbohydrate was obtained by difference and the gross energy of the samples was determined using a Gallenkamp Ballistic Bomb Calorimeter.

\section{Determination of mineral composition}

The composition of minerals and trace elements were determined according to the standard method of the Association of Official Analytical Chemists (2005), Method No 975.23. The ash of each sample (obtained in a crucible, by igniting $2 \mathrm{~g}$ of the samples in a muffle furnace) was digested by adding $5 \mathrm{ml}$ of $2 \mathrm{M} \mathrm{HCL}$, heated slowly for 20 minutes. After heating, it was filtered into a $100 \mathrm{ml}$ volumetric flask. The filtrate was used for the determination of the concentration of each mineral element (Calcium, Potassium and Sodium). For this determination, the Jenway digital flame photometer (PFP7 Model) was used. For the determination of the concentration of Iron, Magnesium and Zinc, Buck Scientific - 200 Atomic Absorption Spectrophotometer -AAS (Buck Scientific, Norwalk) was used (Method No 975.23). Phosphorus was determined by the vanado-molybdate colorimetric method (AOAC, 2005: 975.16).

\section{Determination of vitamin content}

The vitamin contents of the samples were determined using the Metrohm Spectronic 21D Model, at specific wave lengths and extrapolated using precise formulas according to the methods of vitamin assay (2006).

\section{$\beta$-carotene determination}

Vitamin A was determined through ultraviolet absorption measurement at $328 \mathrm{~nm}$ after extraction with chloroform. Calibration curve of vitamin A acetate was made and vitamin A concentration estimated as microgram $\beta$-carotene ( $\mathrm{g} \beta$ carotene). 
Journal of Agriculture and Food Sciences

Volume 19 Number 1, April 2021 pp 63-77

Ariyo, O., Balogun, B., and Solademi E. A.

\section{Ascorbic acid (vitamin C) determination}

The concentration of vitamin $\mathrm{C}$ (ascorbic acid) was determined by redox titration using standardized iodine solution (according to a slightly modified method described by Patel (2017). In this method, ascorbic acid in fruit reacts with iodine to produce dehydroascorbic acid and iodide ions. Excess iodine then reacts with the starch indicator to produce violet colour and indicate the end point of titration.

$$
\text { Ascorbic acid } \mathrm{C}_{6} \mathrm{H}_{8} \mathrm{O}_{6}+\mathrm{I}_{2} \rightarrow \text { Dehydroascorbic acid }\left(\mathrm{C}_{6} \mathrm{H}_{8} \mathrm{O}_{6}\right)+2 \mathrm{I}^{-}
$$

\section{Niacin (vitamin $\mathbf{B}_{3}$ ) determination}

Five grams of blended sample was extracted with $100 \mathrm{ml}$ of distilled water and $5 \mathrm{ml}$ of this solution was drawn into $100 \mathrm{ml}$ volumetric flask and made up to mark with distilled water. Standard solutions of niacin were prepared and absorbance of sample and standard solutions were measured at a wavelength of $385 \mathrm{~nm}$ on a spectrophotometer and niacin concentration of the sample was obtained.

\section{$m g / 100 \mathrm{~g}$ Niacin $=$ Absorbannce $\times$ Dilution factor $\times$ Gradient factor stock}

\section{Pantothenic acid (vitamin B5) determination Ariyo, O., Balogun, B., and Solademi E. A. 63-77}

A gram of sample was weighted into a $250 \mathrm{ml}$ volumetric flask and shaked with $200 \mathrm{ml}$ distilled water for 10 minutes. It was diluted to mark to distilled water. The mixture was filtered through Whatman filter paper into a $100 \mathrm{ml}$ volumetric flask. Five $\mathrm{ml}$ of a liquot of the sample filtrate was pipetted into a $2 \mathrm{ml}$ beaker; $5 \mathrm{ml}$ of $12 \%$ potassium bromide $(\mathrm{KBr}), 10 \mathrm{ml}$ of $\mathrm{KMNO}_{4}$ were added and mixed thoroughly with a glass. The mixture was transferred to a stoppered flask put in a boiling water bath for 10mins. The hot solution cooled in ice for $5 \mathrm{~min}$ and $20 \%$ freshly prepared $\mathrm{H}_{2} \mathrm{SO}_{3}$ was added drop wise to decolonize the excess $\mathrm{KMNO}_{4}$ solution, $10 \mathrm{ml}$ of 2,4 dimitrophenylmrazine $(5 \mathrm{~g} / \mathrm{l})$ was added and mixed thoroughly. The mixture was heated on a steam bath for 15 minutes and cool later to room temperature. The yellow precipitate obtained was dried for 30 minutes in an oven at $100{ }^{\circ} \mathrm{C}$. The dry precipitate is dissolved in hot pyridine solution and mixed thoroughly form in homogenous suspension. The suspension was filtered through a Whatman filter paper into a $50 \mathrm{ml}$ volumetric flask and made up to mark with pyridine solution. All aliquot of the solution above was pipetted into $200 \mathrm{ml}$ of flask $50 \mathrm{ml}$ of distilled water wasadded, followed by the addition $5 \mathrm{ml}$ of $5 \mathrm{M} \mathrm{NaOH}$ solution to develop the due colour. 
Journal of Agriculture and Food Sciences

Volume 19 Number 1, April 2021 pp 63-77

Ariyo, O., Balogun, B., and Solademi E. A.

Absorbance of sample and standard pantothenic and solution of range $10 \mathrm{ug} / \mathrm{ml}-50 \mu \mathrm{g} / \mathrm{ml}$ prepared from $\mu \mathrm{g} / \mathrm{ml}$ stock panthothenic acid were read at a wavelength of $570 \mathrm{~nm}$.

Vit. $B 5(\mu g / 100 g)=$ Absorbannce $\times$ Dilution factor $\times$ Gradient factor

\section{Pyridoxine (vitamin B6) determination}

The vitamin $\mathrm{B}_{6}$ content of the sample was determined by extracting $1 \mathrm{~g}$ of sample with $0.5 \mathrm{~g}$ of ammonium chloride, $45 \mathrm{ml}$ of chloroform and $5 \mathrm{ml}$ of absolute ethanol. The mixture was thoroughly mixed in a separating funnel by shaking for 30 minutes, and $5 \mathrm{ml}$ of distilled water added. The chloroform layer containing the pyridoxine was filtered into a $100 \mathrm{ml}$ volumetric flask and made up to mark with chloroform. 0-10ppm of vitamin B6 standard solutions were prepared and treated in a similar way as sample, and their absorbance measured on Cecil 505E spectrophotometer at $415 \mathrm{~nm}$. The amount of vitamin $B_{6}$ in the sample was then calculated.

$$
\text { Pyridoxine }(\mathrm{mg} / 100 \mathrm{~g})=\frac{\text { Absorbance } \times \text { Gradient factor } \times \text { Dilution factor }}{\text { Weight of sample }}
$$

\section{Tocopherol (vitamin E) determination}

A gram of sample was weighed into a $250 \mathrm{ml}$ conical flask filtered with a reflux condenser. 10 $\mathrm{ml}$ of absolute alcohol and $20 \mathrm{ml}$ of I M alcoholic Sulphuric acid were added. The condenser and flask were wrapped in Aluminium foil and refluxed for 45 minutes and cooled for 15 minutes. 50 $\mathrm{ml}$ of distilled water was added to the mixture and transferred to a $250 \mathrm{ml}$ separating funnel covered with Aluminium foil. The unsaponifiable matters in the mixture were extracted with $5 \mathrm{x}$ $30 \mathrm{ml}$ dimethyl ether. The combined extracts were washed free of acid and dry evaporated at a low temperature and the residues obtained were immediately dissolved in $10 \mathrm{ml}$ absolute alcohol. Aliquots of solutions of the sample and standards $(0.3-3.0 \mathrm{mg}$ vitamin E) were transferred to a $20 \mathrm{ml}$ volumetric flask, $5 \mathrm{ml}$ Absolute Alcohol was added, followed by a careful addition of $1 \mathrm{ml}$ conc. $\mathrm{HNO}_{3}$. The flasks were placed on a water bath at $90{ }^{\circ} \mathrm{C}$ for exactly 3 minutes from the time the alcohol begins to boil. Cool rapidly under running water and adjust to volume with absolute alcohol. The absorbance was measured at $470 \mathrm{~nm}$ against a blank containing $5 \mathrm{ml}$ absolute alcohol and $1 \mathrm{ml}$ conc. $\mathrm{HNO}_{3}$ treated in a similar manner. 
Journal of Agriculture and Food Sciences

Volume 19 Number 1, April 2021 pp 63-77

Ariyo, O., Balogun, B., and Solademi E. A.

$$
\text { Vit. } E(\mu g / 100 g)=\frac{\text { Absorbance } \times \text { Gradient factor } \times \text { Dilution factor }}{\text { Weight of sample }}
$$

\section{Vitamin K determination}

For this determination, $5 \mathrm{~g}$ of sample was weighed into a $250 \mathrm{ml}$ beaker and $30 \mathrm{ml}$ of Butyl alcohol was added. The mixture was thoroughly shaken to obtain a homogenous solution. The resulting mixture was filtered through a filter paper into a $100 \mathrm{ml}$ volumetric flask and made up to mark with butyl alcohol. $10 \mathrm{ml}$ aliquot of the filterate was pipetted into a $30 \mathrm{ml}$ centrifuge tube and 3 drops of 2,4- dinitrophenyl hydrazine was added to develop the blue colour which will subsequently change to bluish green upon addition of $3 \mathrm{ml}$ of alcoholic ammonia. Standard solutions of vitamin $\mathrm{K}$ from $0-20 \mu \mathrm{g} / \mathrm{ml}$ were prepared and treated as samples to obtain a gradient factor. The Absorbances of standards and sample were read at a wavelength of $480 \mathrm{~nm}$.

$$
\text { Vit. } K(\mu g / 100 g)=\frac{\text { Absorbance } \times \text { Gradient factor } \times \text { Dilution factor }}{\text { Weight of sample }}
$$

\section{Determination of antinutrients}

Tannin, saponin, phenol, phlobatannin, anthraquinone cardiac glycosides were determined using a spectrophometer (MetrohmSpectronic 21D) by measuring the various absorbances and comparing it with the specific standard solutions (Jaffe, 2003; Makkar and Becker, 1996; Kim et al., 2006). Phlobatannin, anthraquinone and cardiac glycosides were determined according to the analytical methods of the committee of the Royal Society of Chemistry (1986). Alkaloids were determined according to the method described by (Obadoni \& Ochuko, 2001).

\section{Statistical analysis}

Analyses were carried out in triplicates and data obtained were subjected to Analysis of Variance (ANOVA) to determine statistical differences among means at $\mathrm{p}<0.05$. Results were expressed as Mean \pm Standard Deviation (SD). 
Journal of Agriculture and Food Sciences

Volume 19 Number 1, April 2021 pp 63-77

Ariyo, O., Balogun, O. B., and Solademi E. A.

\section{RESULTS AND DISCUSSION}

The analyses were carried out to determine the changes in nutritional and anti-nutritional composition of the naturally ripened banana samples (NR) with respect to that of the artificially ripened samples $(\mathrm{AR})$ - treated with calcium carbide $\left(\mathrm{CaC}_{2}\right)$.

\section{Proximate composition}

The results of the proximate analysis of the samples presented in Table 1 shows that the naturally ripened banana sample had the highest value of $3.78 \%$ for crude protein than the $\mathrm{CaC}_{2}$ ripened sample $(1.88 \%)$. This same trend was observed for crude fibre and carbohydrates having $2.41 \%$ for naturally ripened samples and $2.09 \%$ for artificially ripened samples and $28.35 \%$ for naturally ripened samples and $23.95 \%$ artificially ripened samples for crude fibre and carbohydrates, respectively. However, the artificially ripened banana samples had a higher fat content $(0.76 \%)$ than the naturally ripened sample $(0.61 \%)$ and moisture content $69.86 \%$ (AR), $63.64 \%(\mathrm{NR})$. The higher carbohydrate and fibre contents in the naturally ripened sample than $\mathrm{CaC}_{2}$ sample agreed with the findings of earlier studies (Yeasmin et al. 2019), and is similar to the outcome of ethrel treated banana fruits (Mahajan et al., 2010). This observation could be attributed to a more efficient gluconeogenesis and higher breakdown of total titratable acidity, which is often higher in artificially ripened than in naturally ripened banana (Islam et al., 2018). The reduced protein composition in $\mathrm{CaC}_{2}$ ripened banana agrees with earlier studies that reported a decrease in the protein content and an increase in the moisture content of artificially ripened banana (Izundu et al., 2016; Fasanya et al., 2019). Higher moisture content in artificially ripened banana has implications on the shelf life and could accelerate post-ripening deterioration and reduced market value. According to Nuhu et al. (2020), increased moisture content in $\mathrm{CaC}_{2}$ artificially ripened banana is an indication that the chemical compound weakens the fibre of the peel so that moisture is easily absorbed. The result of the fat content also conformed to the values obtained for other banana samples cultivated in Africa (Annor et al., 2016; Dotto et al., 2019).

For the ash content of the samples, $1.21 \%$ and $1.49 \%$ was recorded for the naturally ripened and artificially ripened samples, respectively. The results of the ash content are in accordance with the reports by Nuhu et al., (2020) and Fasanya et al., (2019). Since ash relates to the inorganic mineral content of the samples, this is an indication of the probable higher mineral 
Journal of Agriculture and Food Sciences

Volume 19 Number 1, April 2021 pp 63-77

Ariyo, O., Balogun, B., and Solademi E. A.

content of the AR samples, as this depicts that the concentration of minerals on the peel are absorbed by the edible portion of the fruit (Unuigbe \& Ozekhome, 2009).

\section{Mineral composition}

The results of the elemental analysis of the samples in Figure 1 revealed that artificially ripened samples (AR) had the highest content of minerals when compared to that of the naturally ripened banana samples (NR). $\mathrm{CaC}_{2}$ treated banana samples had higher content of calcium $(0.15 \mathrm{mg} / 100$ $\mathrm{g})$, iron $(0.11 \mathrm{mg} / 100 \mathrm{~g})$, potassium $(0.12 \mathrm{mg} / 100 \mathrm{~g})$ and phosphorus $(0.32 \mathrm{mg} / 100 \mathrm{~g})$. Earlier studies have shown similar trend when calcium carbide is used in hastening ripening process. Oguntade and Fatumbi (2019) reported an increased iron content in calcium carbide induced Musa paradisiaca and Maduwanthi and Marapana (2019) revealed that $\mathrm{CaC}_{2}$ treated bananas showed high level of sulphur, and trace amounts of arsenic and phosphorus. Similar findings have been reported with other fruits. Chukwuma et al. (2016) reported an increased mineral content in some fruit samples ripened with calcium carbide.

\section{Vitamin content}

The vitamin content of the samples is presented in Table 2. Biochemically, some vitamins are known to play the role of antioxidants thereby helping to combat free radicals and foods from plant origin have been identified to be good sources of vitamins. The results thus revealed that bananas are good sources of vitamins and should therefore be an essential part of the diet. The vitamin C content of AR $(22.62 \mathrm{mg} / 100 \mathrm{~g})$ significantly decreased $(\mathrm{p}<0.05)$ when compared to NR $(28.87 \mathrm{mg} / 100 \mathrm{~g})$. Similar finding reported by Lestari (2013) showed that vitamin C was detected in calcium carbide treated samples and the highest amount of vitamin $\mathrm{C}$ was observed in untreated sample. Gunasekara et al. (2015) also reported this similar trend. For the B complex vitamins assayed, a decrease in the content was noted in the artificially ripened bananas samples when compared to the naturally ripened samples.

However, the $\beta$-carotene, vitamins $\mathrm{E}$ and $\mathrm{K}$ contents ranged from 123.49 - 127.18 (mcg/100 g), $2.69-1.91(\mathrm{mg} / 100 \mathrm{~g}), 0.23-0.32(\mathrm{mg} / 100 \mathrm{~g})$, respectively and were significantly higher in the artificially ripened bananas samples when compared to the naturally ripened samples. These results were in accordance with the report of Fasanya et al., (2019) who reported an increase in the total carotenoid content of various species of banana treated with calcium carbide and red 
Journal of Agriculture and Food Sciences

Volume 19 Number 1, April 2021 pp 63-77

Ariyo, O., Balogun, B., and Solademi E. A. apple. Joshi et al. (2017) also reported a decrease in the nutritive and antioxidant components of induced fruits. This result indicates that the use of artificial ripening agent, calcium carbide in this case affects the nutritional quality of Cavendish banana, vitamin content in particular. Since fruits constitute the major source of vitamins in the diets of Nigeria, regulating the use of calcium carbide in the Nigerian food system is essential to promote food and nutrition security in the country.

\section{Antinutrients composition}

The antinutrient composition of the samples is presented in Table 3. Antinutrients are important active compounds found in plant-based foods. When at low levels, antinutrients are known to act as phytochemicals, which are relevant to well-being. Antinutrients such as saponins have been shown to reduce blood glucose and/or plasma cholesterol and triglycerols (Popova \& Mihaylova, 2019). A significant decrease was observed in the contents of alkaloids, tannin, saponin, phenol, cardiac glycosides and anthraquinone in the AR group when compared to the naturally ripened group (Table 3). However, there was a significant increase in the phlobatannin content for the artificially ripened group. The toxicity of oxalates for humans is set at $2-5 \mathrm{~g} /$ day and the consumption of diet rich in these antinutrients may result in kidney disease. Hence, the antinutrient levels of the spread in this study are negligible and are therefore regarded as safe for human consumption.

\section{CONCLUSION}

The use of calcium carbide as a ripening agent increases moisture and phlobatannin content, and loss in protein, carbohydrate, fibre, niacin, pantothenic acid, and pyridoxine composition of Cavendish banana. These changes predispose to increased post-harvest losses and reduced nutritional quality which could exacerbate micronutrient malnutrition especially of vitamins. It is therefore imperative to regulate the use of calcium carbide in the Nigerian food system. 
Journal of Agriculture and Food Sciences

Volume 19 Number 1, April 2021 pp 63-77

Ariyo, O., Balogun, B., and Solademi E. A.

\section{REFERENCES}

Abhishek, R. U., Venkatesh, H. N., Manjunath, K., \& Mohana, D. C. (2016). Artificial ripening of fruits-misleading ripe and health risk. Everyman's Science, 6, 364-369.

Akinyemi, S. O. S., Adejoro, M. A., Layade, A. A., \& Adegbite, O. O. (2017). Market structure and performance for plantain and banana. International Journal of Fruit Science, 17:4, 440450. https://doi.org/10.1080/15538362.2017.1360231

Annor, G. A., Asamoah-Bonti, P., \& Sakyi-Dawson E. (2016). Fruit physical characteristics, proximate, mineral and starch characterization of FHIA 19 and FHIA 20 plantain and FHIA 03 cooking banana hybrids. Springerplus, 5 (1), 796. https://doi.org/10.1186/s40064016-2465-1

Association of Official Analytical Chemists,AOAC (2005). Official Methods of Analysis International 18th Edition, International Gaithersburg, Maryland USA.

Chukwuma, O. M., Iroka, F. C., Akachukwu, E. E., Adimonyemma, N. R., \& Mbaukwu, O. A. (2016). A study of the effects of induced ripening on the proximate, biochemical and mineral compositions of Musa sapientum(Banana). International Journal of Food Science and Nutrition, 1.2: 15-20. https://doi.org/10.9734/EJMP/2016/26260

Dotto, J., Matemu, A. O., \& Ndakidemi, P. A. (2019). Nutrient composition and selected physicochemical properties of fifteen Mchare cooking bananas: A study conducted in northern Tanzania. Scientific African, 6, e00150. https://doi.org/10.1016/j.sciaf.2019.e00150

Fasanya, T. A., Olaiya, C. O., \& Karigidi, K. O. (2019). Effect of ripening agents on the nutritional and antioxidant qualities of different banana cultivars. Annals. Food Science and Technology, 20 (4), 877-886.

Food and Agricultural Organization of the United Nations, FAO (2019). FAO forecasts strong growth prospects for global production and trade of tropical fruits. http://www.fao.org/americas/informations/ver/fr/c/1193642 Retrieved 30 November, 2020.

Gunasekara, S. R. W., Hemamali, K. K. G. U., Dayananada, T. G., \& Jayamanne, V. S. (2015). Post-Harvest Quality Analysis Of 'Embul' Banana following Artificial Ripening Techniques. International Journal of Science, Environment and Technology, 4(6), 1625 1632.

Islam, M. N., Imtiaz, M. Y., \& Alam, S. S. (2018). Artificial ripening on banana (Musaspp) samples: Analyzing Ripening agents and change in nutritional parameters.Cogent Food \& Agriculture, 2 (3), 13-16.

Izundu, A. I., Chukwuma, M. O., Adimonyemma, R. N., Akachukwu, E. E., \&Iroka, F. C. (2016). Effects of ripening acceleration methods on the proximate, biochemical and mineral compositions of Musa paradisiaca (plantain). Ewemen Journal of Herbal Chemistry \& Pharmacology Research. 2(1): 26 - 33.

Jaffe, C. S. (2003). Analytical Chemistry of Food. Blackie Academic and Professional, New York, 1:200. 
Journal of Agriculture and Food Sciences

Volume 19 Number 1, April 2021 pp 63-77

Ariyo, O., Balogun, O. B., and Solademi E. A.

Joshi, H., Kuna, A., Lakshmi, M. N., Shreedhar, M., \& Kumar, A. K. (2017). Effect of stage of maturity, ripening and storage on antioxidant content and activity of Mangifera indica L. var. Manjira. International Journal of Food Science and Nutrition, 2(3), 01-09.

Kim, K. H., Tsao, R., Yang, R. \& Cui, S. W. (2006). Phenolic acid profiles and antioxidant activities of wheat bran extracts and the effect of hydrolysis conditions. Food Chem., 95: 466-473. https://doi.org/10.1016/j.foodchem.2005.01.032

Krishna, P. S., Sri, G. K. R., \& Naga Raju K. (2017). Estimation of the nutritional elements present in naturally ripened and artificially ripened bananas. International Journal of Applied Pharmaceutical Sciences. 4(1): 1-10.

Lestari, I. (2013). Effects of carbide and $\mathrm{CaC} 2$ concentration on vitamin- C contents of Banana Kepok. Folia Medica Indonesiana. 49(2): 97-100.

Maduwanthi, S. D. T. \& Marapana, R. A. U. (2019). Induced Ripening Agents and their Effect on Fruit Quality of Banana. Hindawi International Journal of Food Science, Article ID 2520179, 8 pages. https://doi.org/10.1155/2019/2520179

Mahajan, B. V. C., Kaur, T., Gill, M. I. S., Dhaliwal, H. S., Ghuman, B. S., \&Chahil, B. S. (2010). Studies on optimization of ripening techniques for banana. Journal of Food Science and Technology, 47(3), 315-319. https://doi.org/10.1007/s13197-010-0050-0

Makkar, H. P. \& Becker, K. (1996). Nutritional value and antinutritional components of whole and ethanol extracted Moringa oleifera leaves. Animal feed Sci Techno 63:211-238. https://doi.org/10.1016/S0377-8401(96)01023-1

Mesquita, C. B., Leonel, M., Franco, C. M. L., Leonel, S., Garcia, E. L. \& Santos, T. P. R. (2016). Characterization of banana starches obtained from cultivars grown in Brazil. Int. J. Biol. Macromol. 89: 632-639. https://doi.org/10.1016/j.ijbiomac.2016.05.040

Royal Society of Chemistry (1986). Methods of Analysis of analytical methods of the committee of theRoyal Society of Chemistry AMC-RSC, 1986. 222-239.

Methods of Vitamin Assay (2006). 8th Edition, chap. 6, pp. 123-142). Inter-science Publishers.

Nuhu, A. M., Rabi, A. \& Tukur, H. R. (2020). Proximate and elemental analysis of banana fruits (musaspp) ripened with various concentrations of calcium carbide.J. Chem. Soc. Nigeria, 45 (4), 648 -655. https://doi.org/10.46602/jcsn.v45i4.501

Nura, A., Dandag, M. A. \& Wali, N. R. (2018). Effects of artificial ripening of banana (Musaspp) using calcium carbide on acceptability and nutritional quality. Journal of Postharvest Technology, 6(2), 14-20.

Obadoni, B. O. \& Ochuko, P. O. (2001). Phytochemical Studies and Comparative Efficacy of the crude extracts of some homeostatic plants in Edo and Delta States of Nigeria. https://doi.org/10.4314/gjpas.v8i2.16033

Oguntade, B. K. \& Fatumbi T. C. (2019). Effects of three ripening methods on the proximate and mineral composition of plantain (musa paradisiaca) fruits. European Journal of Engineering and Technology, 7 (4): 01-05. 
Journal of Agriculture and Food Sciences

Volume 19 Number 1, April 2021 pp 63-77

Ariyo, O. , Balogun, O. B., and Solademi E. A.

Oyeyinka, B. O., \& Afolayan, A. J. (2020). Potentials of Musa Species Fruits against Oxidative Stress-Induced and Diet-Linked Chronic Diseases: In Vitro and In Vivo Implications of Micronutritional Factors and Dietary Secondary Metabolite Compounds. Molecules, 25(21), 5036. https://doi.org/10.3390/molecules25215036

Patel, P. M. (2017). Determine the ascorbic acid content in selected fruits by using iodine solution in redox titration method and application of ascorbic acid. Der Pharma Chemica, 9(14), 61-63.

Perotti V. E., Moreno A. S., \& Podest'a F. E., (2014). Physiological aspects of fruit ripening: the mitochondrial connection. Mitochondrion, 17: 1-6. https://doi.org/10.1016/j.mito.2014.04.010

Popova, A. \& Mihaylova, D. (2019). Antinutrients in plant-based foods: A Review. The Open Biotechnology Journal, 13:68-76. https://doi.org/10.2174/1874070701913010068

Rahman, M., Hossain, T. B., Hossain, M. S., Sattar, S. \& Das, P. C. (2019). Effect of banana peel extract on storage stability of banana cv. Sagar Food Research, 4 (2): 488- 494. https://doi.org/10.26656/fr.2017.4(2).323

Tejas, M., Harini, R., Sunil C. K. \& Chidanand, D. V. (2019). Effect of Artificial Ripening Techniques on Physico-Chemical Properties of Banana (Musaspp) Variety Poovan. International Journal of Pure and Applied Bioscience,7 (2), 482-489. https://doi.org/10.18782/2320-7051.7453

Unuigbe, O. M. \& Ozekhome, M. C. (2009). Comparative Quality Assessment of Flour from Sun-Dried and Heated Air-Dried Green Banana (Musa sapientum) and Plantain (Musa paradisiaca). Nigeria Food Journal, 27,114-118. https://doi.org/10.4314/nifoj.v27i2.47481

Yeasmin, H., Kobra, K. T., Devi, U. R., Yeasmin, N., \& Begum, A. (2019). Effects of Ripening Agent on Nutritional Composition of Two Varieties of Banana (Musa paradisiaca and Musa acuminata). International Research Journal of Multidisciplinary Studies, 5(2), 245-252. 
Journal of Agriculture and Food Sciences Volume 19 Number 1, April 2021 pp 63-77

Ariyo, O., Balogun, O. B., and Solademi E. A. APPENDICES

Table 1: Effect of ripening agent on the proximate composition of banana

Proximate composition $\quad$ Naturally ripened Artificially ripened

$(\mathrm{NR})$ (AR)

Crude protein $(\%)$

$3.78 \pm 0.06$

$* 1.88 \pm 0.06$

Crude fat $(\%)$

$0.61 \pm 0.01$

$* 0.76 \pm 0.01$

Crude fibre (\%)

$2.41 \pm 0.02$

$* 2.09 \pm 0.02$

Ash (\%)

$1.21 \pm 0.02$

$* 1.49 \pm 0.02$

Crude carbohydrate (\%)

$28.35 \pm 0.06$

$* 23.92 \pm 0.06$

Moisture (\%)

$63.64 \pm 0.02$

$* 69.86 \pm 0.01$

Energy (kcal/100 g)

$1.39 \pm 0.01$

$* 1.42 \pm 0.01$

Data are represented as means of triplicate determinations \pm standard deviation

$*$ Represents significant differences across groups at $\mathrm{p}<0.05$

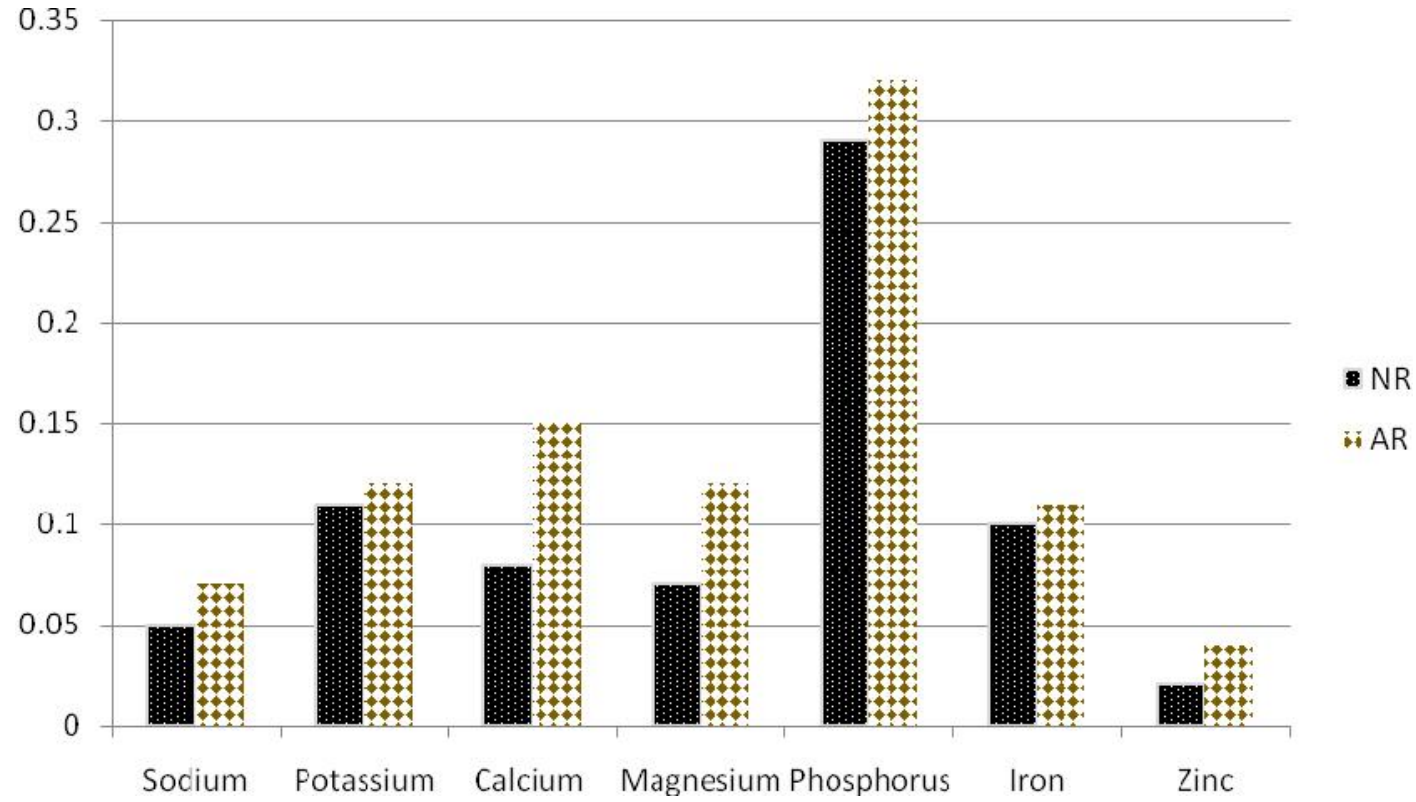

Figure 1: Effect of ripening agent on the mineral composition of banana 
Journal of Agriculture and Food Sciences

Volume 19 Number 1, April 2021 pp 63-77

Ariyo, O., Balogun, O. B., and Solademi E. A.

Table 2: Effect of ripening agent on the vitamin content of banana

$\begin{array}{lcc}\text { Micronutrients }(\mathrm{mg} / 100 \mathrm{~g}) & \text { Naturally ripened (NR) } & \text { Artificially ripened (AR) } \\ \beta \text { carotene (mcg/100 g) } & 123.49 \pm 0.02 & * 127.18 \pm 0.02 \\ \text { Niacin (Vit. B3) } & 0.89 \pm 0.00 & * 0.87 \pm 0.00 \\ \text { Pantothenic acid (Vit. B5) } & 0.27 \pm 0.00 & * 0.25 \pm 0.00 \\ \text { Pyridoxine (Vit. B6) } & 0.29 \pm 0.00 & * 0.27 \pm 0.00 \\ \text { Ascorbic acid (Vit. C) } & 28.87 \pm 0.01 & * 22.62 \pm 3.32 \\ \text { Tocopherol (Vit. E) } & 2.69 \pm 0.02 & * 2.91 \pm 0.01 \\ \text { Phylloquinone (Vit. K) } & 0.23 \pm 0.01 & * 0.32 \pm 0.02\end{array}$

Data are represented as means of triplicate determinations \pm standard deviation

*Represents significant differences across groups at $\mathrm{p}<0.05$

Table 3: Effect of ripening agent on the anti-nutrients composition of banana (mg/100 $\mathrm{g}$ )

\begin{tabular}{lrr}
\hline Anti-nutrients $(\mathrm{mg} / 100 \mathrm{~g})$ & Naturally ripened (NR) & Artificially ripened (AR) \\
\hline Alkaloids & $0.5210 \pm 0.00$ & $* 0.3967 \pm 0.00$ \\
Tannin & $0.0027 \pm 0.00$ & $* 0.0019 \pm 0.00$ \\
Phlobatannin & $0.0014 \pm 0.00$ & $* 0.0070 \pm 0.00$ \\
Saponin & $0.3203 \pm 0.00$ & $* 0.2707 \pm 0.00$ \\
Phenol & $0.2267 \pm 0.00$ & $* 0.2090 \pm 0.00$ \\
Cardiac glycosides & $0.1943 \pm 0.00$ & $* 0.1790 \pm 0.00$ \\
Anthraquinone & $0.0034 \pm 0.00$ & $* 0.0023 \pm 0.00$
\end{tabular}

Data are represented as means of triplicate determinations \pm standard deviation

$*$ Represents significant differences across groups at $\mathrm{p}<0.05$ 